\title{
Length-weight relationship and certain biological aspects of the Indian white shrimp Fenneropenaeus indicus (H. Milne Edwards, 1837) exploited by trawls in the Arabian Sea off Kerala coast, India
}

\author{
S. LAKSHMI PILLAI, E. V. RADHAKRISHNAN, G. MAHESWARUDU AND \\ M. RADHAKRISHNAN \\ ICAR-Central Marine Fisheries Research Institute, Ernakulam North P.O., Kochi - 682018 , Kerala, India \\ e-mail: slakshmipillai@rediffmail.com
}

\begin{abstract}
Length-weight relationship (LWR), sex ratio and maturity of Fenneropenaeus indicus (H. Milne Edwards, 1837), was analysed based on samplings from coastal trawl fishing grounds in the Arabian Sea off Kerala coast, India. The male to female ratio (1:1.27) did not vary significantly from the hypothetical 1:1 ratio. Length at maturity $\left(\mathrm{Lm}_{50}\right)$ was estimated at $122 \mathrm{~mm}$ total length for females. The LWR did not differ significantly between male and female shrimps. The information generated from this study will enhance knowledge on the biology of the species and assist in assessment and management of its stock.
\end{abstract}

Keywords: Length-weight relationship, Maturity, Penaeid shrimp, Sex ratio

Penaeid shrimps have worldwide distribution and constitute an important fishery resource contributing significantly $(44.6 \%)$ to the commercial crustacean fishery of India (CMFRI, 2015). The Indian white shrimp Fenneropenaeus indicus (H. Milne Edwards, 1837) is distributed in the Indo-west Pacific, from east and south-east Africa, India, Sri Lanka, to south China, Philippines and northern Australia (FAO, 1984). It supports commercial fishery in several African countries viz., Kenya, Madagascar, Mosambique, Tanzania and Somalia. It is in demand in international as well as domestic markets and is exported as frozen head-on and de-shelled forms. It is numerically the most important species in the Indian shrimp fishery (Silas et al., 1984). The species is caught in multiday trawl nets (MDTN) that operate for 3 to 4 days and in single day mechanised trawl nets (MTN) that operate during the daylight hours, from depths of 10 to $30 \mathrm{~m}$. In spite of its nutritive value and economic importance in the commercial market, only very few studies have reported on its length-weight relationship (LWR) and length at maturity $\left(\mathrm{Lm}_{50}\right)$ from India and elsewhere (Hall, 1962; Rao, 1968; Lalithadevi, 1987; Rao et al., 1993; Teikwa and Mgaya, 2003; Mehanna et al., 2012). The length-weight relationship (LWR) is useful for computing biomass estimates from length frequency distributions when weight data specific to the time and site are not available to measure changes in robustness of the population, to determine relative condition of the species relative to past or future samples at the same place and season (Schneider et al., 2000). Sex ratio and Lm50 are important to develop knowledge on the reproductive biology of the stock and $\mathrm{Lm}_{50}$ can also aid in determining the optimum age of capture of the species (FAO, 1974). This study reports the fishery, LWR, $\mathrm{Lm}_{50}$ and sex ratio of $F$. indicus from Kerala, as recent studies on these aspects of the species is lacking from the Indian coast.

Samples were collected from trawl landings at Munambam fish landing centre $\left(10^{\circ} .18^{\prime} \mathrm{N} ; 76^{\circ} .17^{\prime} \mathrm{E}\right)$ which is one of the major fish landing centres on the southwest coast of India, during February 2011 to February 2012 by weekly random sampling (Fig. 1).

Sampling was done throughout the year except during seasonal trawl ban (July) and during August to September when the species was not landed. The samples were preserved in ice and brought to the laboratory for further analysis. Samples were first segregated sex-wise into males and females based on the presence of petasma and thelycum to ascertain their monthly sex ratio. Individual specimens were measured for their total length (TL, mm) using a measuring scale and individual wet weight (g) using single pan electronic balance. Sex ratio was estimated each month and Chi square $\left(\chi^{2}\right)$ test (Snedecor and Cochran, 1967) was done to determine its variation from the hypothetical sex ratio of $1: 1$.

The $\mathrm{Lm}_{50}$ of females was calculated from the proportion of mature females in $1 \mathrm{~mm}$ class intervals 


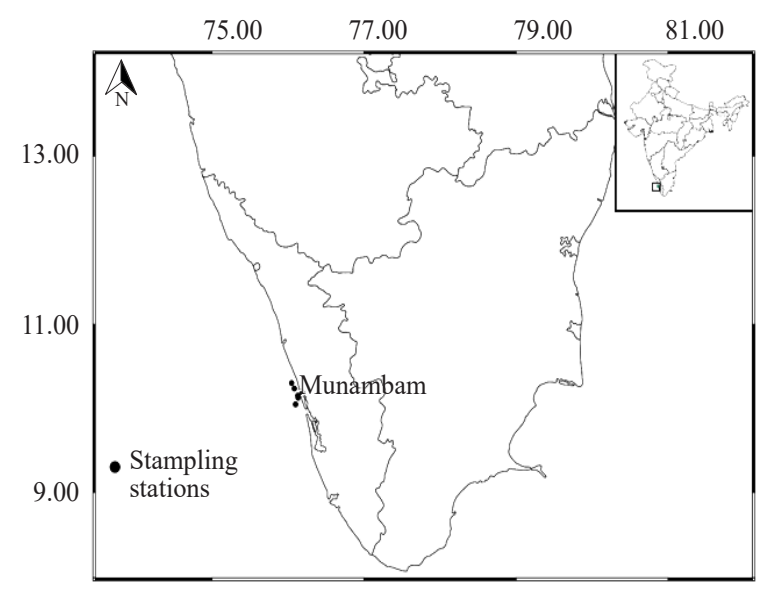

Fig. 1. Map showing the fishing sites off Munambam along the Kerala coast of Arabian Sea

and fitted to a logistic curve using nonlinear least square method (King, 2007): $\mathrm{P}=1 /\left\{\left(1+\exp \left(\mathrm{r}-\left(\mathrm{L}_{-} \mathrm{L}_{50}\right)\right)\right\}\right.$, where, $\mathrm{P}=$ Proportion of mature females, $\mathrm{r}=$ Slope of the curve and $\mathrm{L}_{50}=$ Length at $50 \%$ maturity. The total length that corresponded to a proportion of 0.5 of sexually mature females was taken as the $\mathrm{Lm}_{50}$.

The LWR was determined for males, females and sexes pooled by the equation $\mathrm{W}=\mathrm{aL}^{\mathrm{b}}$ (Le Chren, 1951) where ' $\mathrm{W}$ ' = Weight $(\mathrm{g})$ of the specimen, ' $\mathrm{L}$ ' = Total length $(\mathrm{mm})$, ' $a$ ' = Intercept and ' $b$ ' = the slope of the linear regression. The degree of relationship between the variables was computed by co-efficient of determination $\left(r^{2}\right)$. Analysis of co-variance was done to test the difference in LWR between sexes.

The number of females used for the study was 708 , with total length ranging from 91 to $200 \mathrm{~mm}$ and the number of males was 656, with total length ranging from 106 to $180 \mathrm{~mm}$. The LWR was estimated as: $\mathrm{W}=0.000000099 \mathrm{~L}^{3.4}$ for females $\left(\mathrm{R}^{2}=0.98\right)$ and $\mathrm{W}=0.000001308 \mathrm{~L}^{3.3}\left(\mathrm{R}^{2}=0.95\right)$ for males. As the LWR did not significantly differ between males and females ( $p>0.05$ ) the data was pooled (Fig. 2) to derive a common equation $\mathrm{W}=0.00000108 \mathrm{~L}^{3.3}\left(\mathrm{R}^{2}=0.97\right)$. The correlation coefficient ' $r$ ' obtained in the study (females 0.98 , males 0.95 , pooled 0.97 ) was high, which denotes that as the length of the shrimp increases the weight also increases proportionally. High $\mathrm{r}^{2}$ values indicate good fit of the regression model. These results indicate that growth in F. indicus is not influenced by sex. Earlier studies report ' $b$ ' values of 3.4 and 3.5 for sexes pooled data from the south-east coast of India (Lalithadevi, 1986; Rao, 1993) and 'b' values of 3.03 for male, 3.03 for female and 2.97 for pooled samples from Tanzanian waters (Teikwa and Mgaya, 2003). Significant difference between sexes was observed only by Rao (1993).

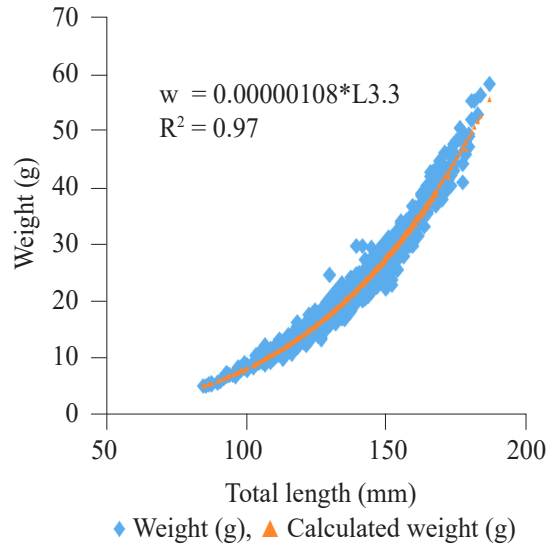

Fig. 2. Length-weight relationship of $F$. indicus (sexes pooled)

About 3059 shrimp (1578 males and 1481 females) ranging from 91 to $201 \mathrm{~mm}$ TL were examined for size frequency and sex ratio. The average mean length of females was greater than males (143.2 and $140.8 \mathrm{~mm}$ ). Number of females was maximum in the 131-135 mm length group and number of males in 141-145 mm (Fig. 3).

George et al. (1963) reported the size range from the region as 103 to 193 for males and 108 to 188 for females. Size at recruitment in the trawl landings was lower in females (91 mm TL) than in males (106 mm TL). Mohamad and Rao (1971) observed that the shrimps leave the estuary at six months age $(80 \mathrm{~mm}$ TL). Male to female ratio was $1: 1.27$ and did not vary significantly $(p>0.05)$ from 1:1. Females dominated the fishery only during March $\left(\chi^{2}=6.97, p>0.05\right)$ and in the remaining months followed 1:1 sex ratio. Significant difference in the sex ratio of $F$. indicus has been reported from Kochi, south-west coast of India (George and Rao, 1962) and in the fishery of Chilka Lake, south-east coast of India (Rao, 1967). Mehanna (2012) reported dominance of females from Oman waters off Arabian Sea and Teikwa and Mgaya (2003) from Bogomoyo coastal waters, Tanzania.

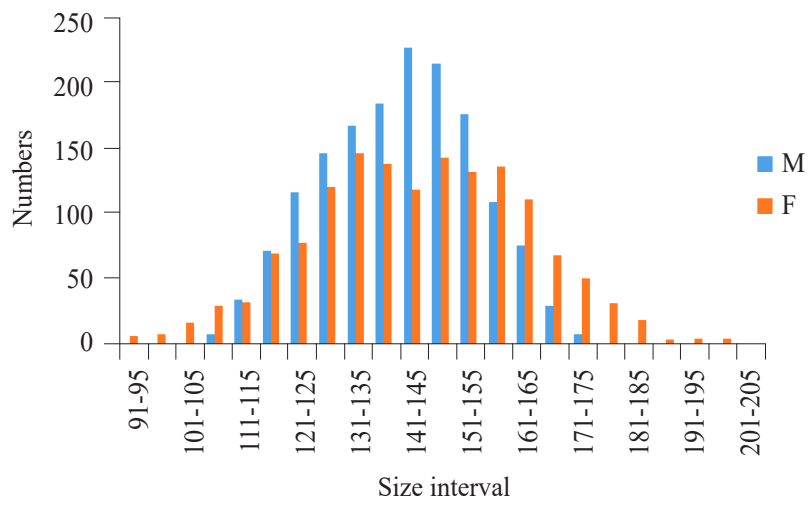

Fig. 3. Length frequency distribution of $F$. indicus during the study period 
Mature females were present throughout the period. Mature and spent females, ranging in length from 116 to $200 \mathrm{~mm}$ constituted 9.9 and $53 \%$ of the sampled population (Fig. 4) respectively.

The minimum size of mature female shrimp was $116 \mathrm{~mm}$ TL and the $\mathrm{Lm}_{50}$ was estimated at $122 \mathrm{~mm} \mathrm{TL}$ (Fig. 5).

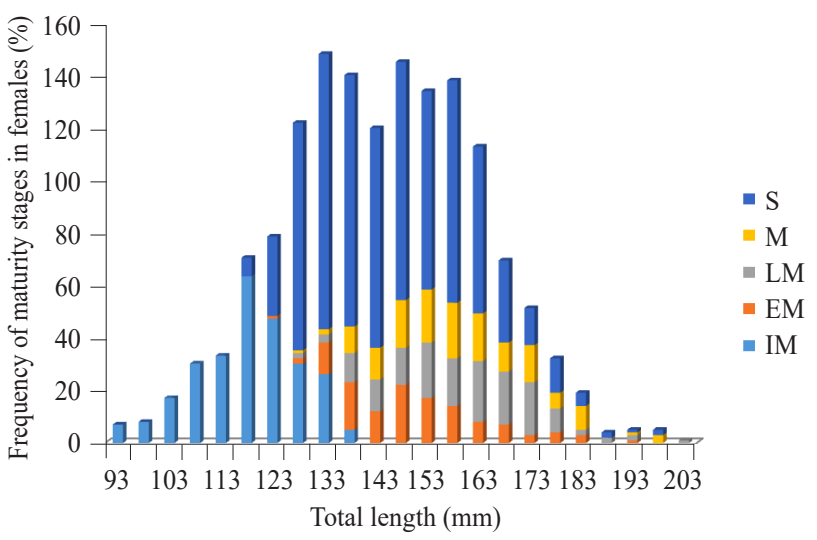

Fig. 4. Length frequency distribution of immature (IM), early maturing (EM), late maturing (LM), mature (M) and spent (S) female $F$. indicus

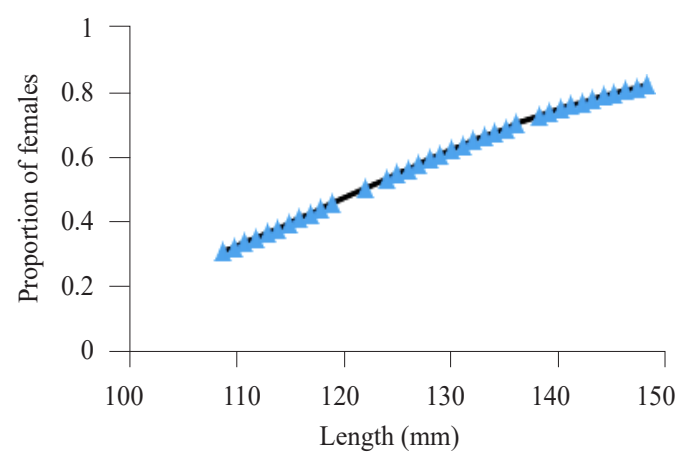

Fig. 5. Length at maturity $\mathrm{Lm}_{50}$ in female $F$. indicus

Studies from Sri Lankan waters reported the size at maturity as $131.6 \mathrm{~mm}$ (Jayawardane et al., 2002). Earlier studies by Rao (1968), Lalithadevi (1987) and Rao et al. (1993) from India reported the size at maturity as 134, 125 and $120 \mathrm{~mm}$ TL respectively. Based on $\mathrm{Lm}_{50}$ obtained in the present study, it is advisable to fix the legal size of capture as $122 \mathrm{~mm}$ when they attain an average weight of $11 \mathrm{~g}$, thus protecting the juveniles. This will assist in maintaining the spawning stock and curb the size of the resource caught, ultimately leading to profit for the fisherfolk.

\section{Acknowledgements}

The authors thank the Director ICAR-CMFRI, Kochi for providing the facilities to carry out the study. The first two authors acknowledge the ICAR-National Innovations in Climate Resilient Agriculture (NICRA) project for funding the study.

\section{References}

CMFRI 2015. Annual Report 2014-15. I-ICAR-Central Marine Fisheries Research Institute, Kochi, India, 270 pp.

FAO 1974. Sex, maturity and fecundity. In: Holden, M. J. and Raitt, D. F. S. (Eds.), Manual of fisheries science, Part 2 - Methods of resource investigation and their application. Food and Agriculture Organisation, Rome.

FAO 1984. FAO species identification sheets for fishery purposes. Fishing area 51 (West Indian Ocean). Food and Agriculture Organisation, Rome. 190 pp.

George, M. J. 1962. Observations on the size groups of Penaeus indicus (Milne Edwards) in the commercial catches of different nets from the backwaters of Cochin. Indian J. Fish., 9: 468-475.

Geroge, M. J., Raman, K. and Nair, K. 1963. Observations on the offshore prawn fishery of Cochin. Indian J. Fish., 10(2A): 460-499.

Hall, D. N. F. 1962. Observations on the taxonomy and biology of some Indo-West Penaeidae (Crustacea Decapoda) Fish. Publ., Colonial Office, London, 17: 1-229.

Jayawardane, P. A., McLusky, D. S. and Tytler, P. 2002. Estimation of population parameters and stock assessment of Peneaus indicus (H. Milne Edwards) in the western coastal waters of Sri Lanka. Asian Fish. Sci., 15: 155-166.

King, M. 2007. Fisheries biology, assessment and management, $2^{\text {nd }}$ edn. Blackwell Scientific Publications, Oxford, 381 pp.

Lalithadevi, S. 1986. Growth and population dynamics of the Indian white prawn Penaeus indicus H. M. Edwards from Kakinada. Proceedings of the Indian Academy of Science, 96(5): 529- 639 .

Lalithadevi, S. 1987. Biology of Indian white shrimp Penaeus indicus H.M. Edwards from Kakinada, east coast of India, Indian J. Mar. Sci., 16:246-248.

Le Cren, C. D. 1951. The length weight relationship and seasonal cycle in gonad weight and condition in perch Perca fluvitalis. J. Anim. Ecol., 20: 201- 209.

Mehanna, S. F., Al-Mamary, J. and Al-Kharusi, L. 2012. Fishery characteristics and population dynamics of Indian white shrimp Fenneropenaeus indicus from Arabian Sea, Sultanate of Oman. Turk. J. Fish. Aquat. Sci., 12: 239-246.

Mohamad, K. H. and Rao, P. V. 1971. Estuarine phase in the life history of the commercial prawns of the west coast of India. J. Mar. Biol. Ass. India.13(2): 149-161.

Rao, A. V. P. 1967. Some observations on the biology of Penaeus indicus $\mathrm{H}$. Milne Edwards and Penaeus monodon Fabricius from the Chilka Lake, Indian J. Fish., 14 (1 \&2): 251-270. 
Rao, G. S., Subramaniam, V. T., Rajan, K. N., Samson Manickam, M. and Maheswarudu, G. 1993. Stock assessment of Penaeus spp. off the east coast of India. Indian J. Fish., 40: 1-19.

Rao, P. V. 1968. Maturation and spawning of penaeid prawns from the south-west coast of India. FAO, Fish Rep., 57(2): 285-301.

Silas, E. G., George, M. J. and Jacob, T. 1984. A review of the shrimp fisheries of India: A scientific basis for the management of the resources. In: Gulland, J. A. and Rothschild, B. J. (Eds.), Penaeid shrimps: Their biology and management. Fishing News (Books) Ltd., Surrey, p. 83-103.
Snedecor, G. W. and Cochran, W. C. 1967. Statistical methods $6^{\text {th }}$ edn., Oxford and IBH Publishing Co., New Delhi, India, $593 \mathrm{pp}$.

Schneider, James C., Laarman, P. W. and Gowing, H. 2000. Lengthweight relationships. In: Schneider, J. C. (Ed.), Manual of fisheries survey methods II: with periodic updates. Michigan Department of Natural Resources, Fisheries Special Report 25, Ann Arbor.

Teikwa, M. D. and Mgaya, Y. D. 2003. Abundance and reproductive biology of the penaeid prawns of Bagamoyo coastal waters, Tanzania. Western Indian Ocean J. Mar. Sci., 2(2): 117-126. 